\title{
HYDROMETALLURGICAL METHODS OF GALVANIC SLUDGE PROCESSING
}

\author{
'Silvie BROŽOVÁ, 'Jaromír DRÁPALA, 'Šárka LANGOVÁ, 'Jiřina VONTOROVÁ,

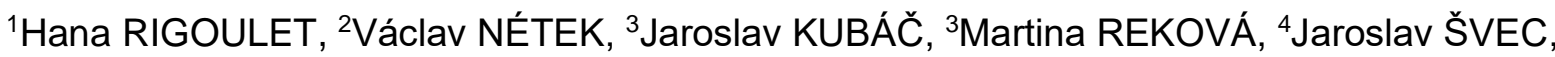

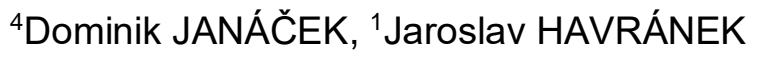 \\ ${ }^{1}$ VSB - Technical University of Ostrava, Ostrava, Czech Republic, EU, silvie.brozova@vsb.cz \\ 2University of Entrepreneurship and Law, Ostrava, Czech Republic, EU, vaclav.netek@vspp.cz \\ ${ }^{3}$ GALVA s.r.o. Držovice, Czech Republic, EU, kubac@galva.cz \\ ${ }^{4}$ WANZL spol. s r.o., Hněvotín, Czech Republic, EU, Jaroslav.Svec@wanzl.cz
}

https://doi.org/10.37904/metal.2021.4233

\begin{abstract}
The paper deals with the possibility of obtaining zinc and iron from waste galvanic sludge, which arises during galvanic plating. The practical part describes laboratory experiments of the hydrometallurgical process of leaching in acids, with the addition of oxidizing agents. Subsequent chemical analyzes of leachate and leachate. Finally, other procedures for possible recovery of metals as secondary raw materials are indicated.
\end{abstract}

Keywords: Metals, galvanic sludge, hydrometallurgical process, leaching

\section{INTRODUCTION}

The reserves of rich ores from which it is technologically possible and economically feasible to extract nonferrous metals by existing widely used technological processes are decreasing. Therefore, the study of new technological processes for the processing of polymetallic ores and concentrates with non-standard nonferrous metal content other than respecting environmental standards is one of the current problems of metallurgical mining. The use of pyrometallurgical processes is not environmentally friendly in terms of the production of large amounts of $\mathrm{SO}_{2}$ production [1]. In recent years, hydrometallurgical processes have been the subject of much research because they allow the processing of complex ores, concentrates and wastes and reduce environmental pollution.

Recovering waste materials and recovering metals from various secondary sources is of major importance due to the economic and environmental benefits. Zinc is one of the most popular and versatile metal that finds a wide range of applications including plating, coating and alloying with other metals. Commercially, zinc can be ranked as the third most common metal after aluminium and copper [1-3]. Currently, most zinc metal is produced by the Roast-Leach-Electro (RLE) process [4]. The high demand for zinc has also led the industry to exploit secondary sources such as zinc waste, zinc slag and leach residues as potentially valuable resources [5]. One of the options to recover zinc and iron from galvanic plating waste materials is sludge.

Zinc typically provides 50 to 75 years of corrosion protection for iron and steel in many environments [5]. Empirical data collected on the performance of galvanized steel in environments ranging from industrial to marine to suburban and rural suggest that zinc can prevent corrosion of the underlying steel more than other surface treatments because it corrodes at a rate of about 1/30th that of iron. It has been estimated that the application of $30-70 \mathrm{~kg}$ of zinc (requiring $125-300 \mathrm{kWh}$ of energy to produce) can extend the life of one ton of steel products (requiring $2500 \mathrm{kWh}$ ) by a factor of three to five [6]. Zinc coated steel is commonly used in indoor and outdoor atmospheres, fresh or seawater, soil, concrete and/or in contact with other metals, treated wood, under extreme temperatures and also for storage of hundreds of different chemicals [7-9]. 
Recycling of HDG by-products allows zinc to be recovered as a metal or other compounds and returned to the production cycle, thereby reducing the input of primary metal and improving environmental protection [2,9]. Zinc sludge can be treated by both pyrometallurgical [10 -12] and hydrometallurgical [13-18] methods.

The latter are efficient, economical, relatively clean and can be adapted on a small or medium industrial scale. Literature data on hydrometallurgical treatment of wastes is rather limited and mainly considers the leaching method in sulphuric [14] or hydrochloric acid [13].

This paper reports the results of preliminary studies on the hydrometallurgical treatment of galvanic sludge produced by industrial sources. Currently, this waste is managed domestically by zinc producers or sold to foreign recyclers. The objective of the research was to determine the effect of solid to liquid ratio, agitation rate and temperature on the efficiency of zinc leaching with sulphuric acid with the addition of the oxidizing agents hydrogen peroxide and ozone. The results obtained will help to develop further process for recycling zinc and iron and their further use as secondary raw material [17-20].

The aim of the work is to obtain zinc and iron from leaching of galvanic sludge. A sub-objective is a theoretical analysis of hydrometallurgical processes. The practical part aims at sample treatment, subsequent leaching of waste sludge in $10 \%$ and $30 \%$ sulphuric acid. The thesis concludes with an evaluation of the conditions under which the highest yield of zinc and iron is obtained after leaching of galvanic sludge and a proposal for further procedure.

\section{BASIC CHARACTERISTICS OF ZINC- AND IRON-CONTAINING WASTES AND THE LEACHING PROCESS}

At present, waste residues are mainly treated in two ways, pyrometallurgical and hydrometallurgical. Pyrometallurgical processes are expensive due to the large amount of energy required to maintain high processing temperatures above $1000^{\circ} \mathrm{C}$ and high pressures [7-12].

Hydrometallurgical processes are based on the leaching of pretreated enriched ore, which is often sulphate roasted, to obtain sulphates that are highly soluble in suitable leaching reagents. The products are two phases, the leachate, a solid residue, and the leach, which contains the metal of interest. From the leachate we then recover the metal by a number of processes. With a relatively rich feedstock, a number of metals will still be present in the leachate, which can be further leached with leaching reagents to obtain the leachate and the depleted waste leachate. From the leach liquor, the metals are recovered by the procedures described earlier.

The galvanic sludges, which contain larger amounts of heavy metals, constitute waste that is suitable for recycling. These are generated during the treatment of waste water from the operation of the galvanic plant. It is a mixture of metal hydroxides mainly iron, zinc, chromium and others. The sludge is sedimented in reaction pits and pumped to a sludge lagoon after sedimentation is complete. From there they are dewatered by a sludge pump in a sludge tank. The dewatered sludge is then collected in containers. Hydrometallurgical methods are used for sludge treatment. Acid or alkaline leaching is used to convert the metals of interest into a leachate. Most of the waste substances do not dissolve in the environment or are converted to a difficult-todissolve compound. The leachate is then treated by electrolysis to separate the individual metals [12-20].

\section{EXPERIMENTS}

The aim of the experimental part was to verify the leaching conditions on the quantity of the metal of interest obtained. A sample of waste electroplating sludge was treated by drying and crushing to the particle size. That was followed by a leaching process where sulphuric acid was chosen as the leaching agent for different dilutions. The conditions were set as in previous experiments [7].

The main part of the experimental work was to determine the most suitable conditions for obtaining the maximum yield of zinc and iron from the waste electroplating sludge. Leaching was carried out in sulphuric 
acid. Samples were analyzed for zinc and iron content, in the laboratories of the Faculty of Materials and Technology. The input chemical analysis of the sample is given in Table 1.

Table 1 The amount of metals of interest in galvanic sludges measured by ED-XRF

\begin{tabular}{|c|c|c|c|c|}
\hline \multirow{3}{*}{ Element } & \multicolumn{3}{|c|}{ Galvanic sludges } & \multirow{3}{*}{ Average } \\
\hline & \multicolumn{3}{|c|}{ Measurement (wt\%) } & \\
\hline & 1 & 2 & 3 & \\
\hline $\mathrm{Zn}$ & 15.93 & 15.95 & 15.84 & 15.91 \\
\hline $\mathrm{Fe}$ & 12.30 & 12.31 & 12.30 & 12.30 \\
\hline
\end{tabular}

Waste sludge samples were pretreated by drying under normal conditions and size homogenization by hand grinding (Figure 1).

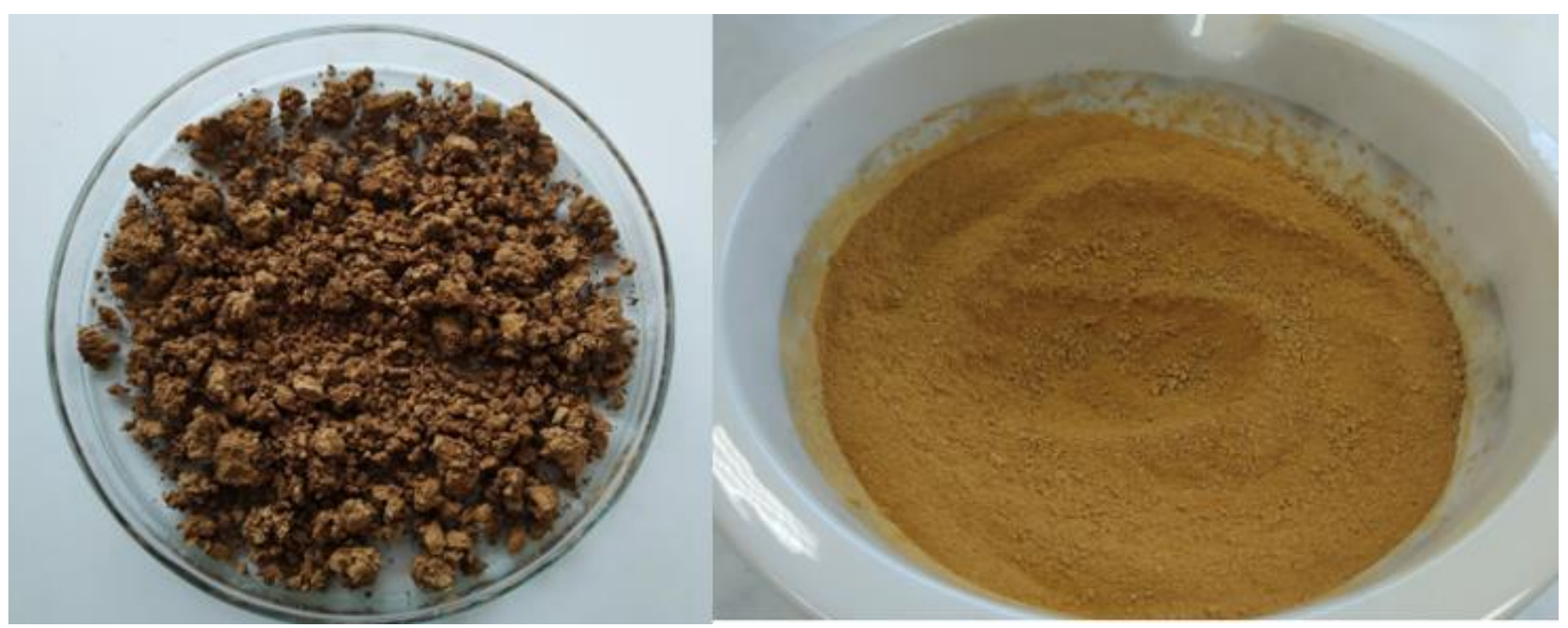

Figure 1 Preparation of samples for leaching

For the hydrometallurgical leaching method, sulphuric acid in two dilutions of $10 \%, 30 \%$ was chosen. This selection was made according to the analysis of literature sources dealing with the leaching of waste materials. We wanted to compare the amount of metal recovered by changing the leaching solution conditions. Leaching solutions were prepared from concentrated acid by diluting to the desired solutions. Another condition in the experiments was the addition of an oxidizing agent in the form of $\mathrm{H}_{2} \mathrm{O}_{2}$ and with the addition of ozone, at temperatures of 40 and $60^{\circ} \mathrm{C}$ for 6 hours.

\section{Leaching procedure}

Beakers with prepared samples of $200 \mathrm{ml}$ of $10 \%, 30 \%$ sulphuric acid along with $50 \mathrm{~g}$ of weighed sample of waste galvanic sludge, (1:4 ratio) were placed on electromagnetic stirrers. The desired temperatures $\left(40^{\circ} \mathrm{C}\right.$ and $60^{\circ} \mathrm{C}$ ) were individually set on each electromagnetic stirrer. After the specified time $(6 \mathrm{~h})$, the leaching process was terminated and the leachate and leachate were separated by filtration. The leach was collected after two hours to determine more accurately the amount of metal that had passed into the leach. The leachate was collected after the experiment was completed after $6 \mathrm{~h}$.

The samples obtained after leaching (leaching substance, leachate) were chemically analyzed for zinc and iron content. (Tables 2, 3). 
Table 2 The final zinc and iron content of the leaching substance

\begin{tabular}{|c|c|c|c|c|c|c|}
\hline \multirow{8}{*}{$\begin{array}{l}\text { sample after } \\
\text { leaching } \\
10 \% \mathrm{H}_{2} \mathrm{SO}_{4}\end{array}$} & \multicolumn{3}{|c|}{$40{ }^{\circ} \mathrm{C}$} & \multicolumn{3}{|c|}{$60{ }^{\circ} \mathrm{C}$} \\
\hline & Addition, time & $\mathrm{Zn}(\mathrm{mg} / \mathrm{l})$ & $\mathrm{Fe}(\mathrm{mg} / \mathrm{l})$ & Addition, time & Zn $(\mathrm{mg} / \mathrm{l})$ & $\mathrm{Fe}(\mathrm{mg} / \mathrm{l})$ \\
\hline & $\mathrm{H}_{2} \mathrm{O}_{2} 2 \mathrm{~h}$ & 10800 & 0.805 & $\mathrm{H}_{2} \mathrm{O}_{2} 2 \mathrm{~h}$ & 16400 & 4.52 \\
\hline & $\mathrm{H}_{2} \mathrm{O}_{2} 4 \mathrm{~h}$ & 11100 & 2.77 & $\mathrm{H}_{2} \mathrm{O}_{2} 4 \mathrm{~h}$ & 24400 & 15.8 \\
\hline & $\mathrm{H}_{2} \mathrm{O}_{2} 6 \mathrm{~h}$ & 11400 & 5 & $\mathrm{H}_{2} \mathrm{O}_{2} 6 \mathrm{~h}$ & 36100 & 18.6 \\
\hline & $\mathrm{O}_{3} 2 \mathrm{~h}$ & 18600 & 4.7 & $\mathrm{O}_{3} 2 \mathrm{~h}$ & 17300 & 344 \\
\hline & $\mathrm{O}_{3} 4 \mathrm{~h}$ & 19900 & 75.7 & $\mathrm{O}_{3} 4 \mathrm{~h}$ & 22300 & 820 \\
\hline & $\mathrm{O}_{3} 6 \mathrm{~h}$ & 40000 & 2150 & $\mathrm{O}_{3} 6 \mathrm{~h}$ & 40200 & 4360 \\
\hline \multirow{8}{*}{$\begin{array}{c}\text { sample after } \\
\text { leaching } 30 \% \\
\mathrm{H}_{2} \mathrm{SO}_{4}\end{array}$} & \multicolumn{3}{|c|}{$40^{\circ} \mathrm{C}$} & \multicolumn{3}{|c|}{$60{ }^{\circ} \mathrm{C}$} \\
\hline & Addition, time & Zn (mg/l) & $\mathrm{Fe}(\mathrm{mg} / \mathrm{l})$ & Addition, time & Zn (mg/l) & $\mathrm{Fe}(\mathrm{mg} / \mathrm{l})$ \\
\hline & $\mathrm{H}_{2} \mathrm{O}_{2} 2 \mathrm{~h}$ & 40200 & 6980 & $\mathrm{H}_{2} \mathrm{O}_{2} 2 \mathrm{~h}$ & 47500 & 8480 \\
\hline & $\mathrm{H}_{2} \mathrm{O}_{2} 4 \mathrm{~h}$ & 31600 & 5781 & $\mathrm{H}_{2} \mathrm{O}_{2} 4 \mathrm{~h}$ & 35400 & 6890 \\
\hline & $\mathrm{H}_{2} \mathrm{O}_{2} 6 \mathrm{~h}$ & 31700 & 6200 & $\mathrm{H}_{2} \mathrm{O}_{2} 6 \mathrm{~h}$ & 43700 & 8420 \\
\hline & $\mathrm{O}_{3} 2 \mathrm{~h}$ & 29700 & 5140 & $\mathrm{O}_{3} 2 \mathrm{~h}$ & 42400 & 7260 \\
\hline & $\mathrm{O}_{3} 4 \mathrm{~h}$ & 19500 & 3660 & $\mathrm{O}_{3} 4 \mathrm{~h}$ & 27920 & 5200 \\
\hline & $\mathrm{O}_{3} 6 \mathrm{~h}$ & 15600 & 4000 & $\mathrm{O}_{3} 6 \mathrm{~h}$ & 13700 & 4360 \\
\hline
\end{tabular}

Table 3 The resulting content of zinc and iron in the leachate

\begin{tabular}{|c|c|c|c|c|c|c|}
\hline \multirow{4}{*}{$\begin{array}{c}\begin{array}{c}\text { sample } \\
\text { after } \\
\text { leaching }\end{array} \\
10 \% \\
\mathrm{H}_{2} \mathrm{SO}_{4}\end{array}$} & \multicolumn{3}{|c|}{$40^{\circ} \mathrm{C}$} & \multicolumn{3}{|c|}{$60^{\circ} \mathrm{C}$} \\
\hline & Addition, time & Zn (wt\%) & $\mathrm{Fe}(w t \%)$ & Addition, time & Zn (wt\%) & $\mathrm{Fe}(w t \%)$ \\
\hline & $\mathrm{H}_{2} \mathrm{O}_{2} 6 \mathrm{~h}$ & 5.21 & 3.25 & $\mathrm{H}_{2} \mathrm{O}_{2} 6 \mathrm{~h}$ & 2.61 & 3.58 \\
\hline & $\mathrm{O}_{3} 6 \mathrm{~h}$ & 2.11 & 2.75 & $\mathrm{O} 36 \mathrm{~h}$ & 2.08 & 2.39 \\
\hline \multirow{4}{*}{$\begin{array}{c}\text { sample } \\
\text { after } \\
\text { leaching } \\
30 \% \\
\mathrm{H}_{2} \mathrm{SO}_{4}\end{array}$} & \multicolumn{3}{|c|}{$40^{\circ} \mathrm{C}$} & \multicolumn{3}{|c|}{$60^{\circ} \mathrm{C}$} \\
\hline & Addition, time & Zn (wt\%) & $\mathrm{Fe}(w t \%)$ & Addition, time & Zn (wt\%) & $\mathrm{Fe}(\mathrm{wt} \%)$ \\
\hline & $\mathrm{H}_{2} \mathrm{O}_{2} 6 \mathrm{~h}$ & 5.47 & 0.86 & $\mathrm{H}_{2} \mathrm{O}_{2} 6 \mathrm{~h}$ & 2.26 & 0.38 \\
\hline & $\mathrm{O}_{3} 6 \mathrm{~h}$ & 1.76 & 0.26 & $\mathrm{O} 36 \mathrm{~h}$ & 1.21 & 0.11 \\
\hline
\end{tabular}

\section{CONCLUSION}

The aim of this work was to verify the leaching conditions for the amount of zinc and iron metal of interest obtained. A sample of waste galvanic sludge was treated and leached in sulphuric acid solution at several dilutions of $10 \%$ and $30 \%$ for 6 hours and temperatures of 40 and $60^{\circ} \mathrm{C}$. The oxidizing agent hydrogen peroxide and ozone were added. The ratio of K:P was also an important factor. In this case it was 1:4, i.e. $50 \mathrm{~g}$ of sample and $200 \mathrm{ml}$ of $10 \%$ and $30 \%$ sulphuric acid.

\section{ACKNOWLEDGEMENTS}

This work was solved in the frame of the project of Technological Agency of Czech Republic No. SS1020312 „Innovative technology of the closed loop water circulation in the electro-galvanizing 


\section{process and processing of metal waste - sludges and filtration cakes from the galvanizing plant", SP2021/62 and SP2021/41.}

\section{REFERENCES}

[1] GORDON, R.B., GRAEDEL, T.E., BERTRAM, M., FUSE, K., LIFSET, R., RECHBERGER, H., SPATARIS. The characterization of technological zinc cycles. Resources, Conservation and Recycling. [online]. 2003, vol. 39, pp. 107-135. Available from: https://doi.org/10.1016/S0921-3449(02)00166-0.

[2] DVOŘ́K, P., JANDOVÁ, J. Hydrometallurgical recovery of zinc from hot dip galvanizing ash. Hydrometallurgy. [online]. 2005, vol. 77, pp. 29-33. Available from: https://doi.org/10.1016/j.hydromet.2004.10.007.

[3] BARAKAT, M.A., MAHMOUD, M.H.M., SHEHATA, H. Hydrometallurgical recovery of zinc from fine blend of galvanization processes. Separation Science and Technology. [online]. 2007, vol. 41, pp. 1757-1772. Available from: https://doi.org/10.1080/01496390600588747.

[4] BROŽOVÁ, S., INGALDI, M., ŠPERLÍN, I. Economical aspects of high-temperature heating utilization for industrial waste treatment. In METAL 2013: $22^{\text {nd }}$ International Conference on Metallurgy and Materials. Ostrava: TANGER, 2013, pp. 1735-1739.

[5] BARICOVA, D., PRIBULOVA, A., ROSOVA, A. Steelmaking slag - waste or valuable secondary raw material. In $13^{\text {th }}$ International Multidisciplinary Scientific Geoconference, SGEM 2013. Albena, BULGARIA, 2013, Book Series: International Multidisciplinary Scientific GeoConference SGEM, 2013, pp. 437-442.

[6] VONTOROVÁ, J., MOHYLA, P. Use of GDOES method for evaluation of the quality and thickness of hot dip galvanised coating. Transactions of the Institute of Metal Finishing. [online]. 2018, vol. 96, no. 6, pp. 313-318. Available from: https://doi.org/10.1080/00202967.2018.1520531. WOS:000447137500007.

[7] BROŽOVÁ, S., DRÁPALA, J., MICZKOVÁ, J., HAVRÁNEK, J. Possibilities of obtaining zinc and iron after leaching of galvanic sludges. In: METAL 2020 $29^{\text {th }}$ International Conference on Metallurgy and Materials. Ostrava: TANGER, 2020, pp. 892-896.

[8] SOKIĆ, M., MARKOVIĆ, B., STANKOVIĆ, S., KAMBEROVIĆ, Ž., ŠTRBAC, N., MANOJLOVIĆ, V., PETRONIJEVIĆ, N. Kinetics of chalcopyrite leaching by hydrogen peroxide in sulfuric acid. Metals. [online]. 2019, vol. 9, p. 1173. Available from: https://doi.org/10.3390/met9111173

[9] MISHRA, B., LUDWIG, CH., DAS, S. REWAS 2008: Global Symposium on Recycling. Waste, Treatment and Clean Technology. 2008. ISBN 978-0-87339-726-1.

[10] Galvanic zinc coating. Galva, s.r.o [online]. [cit.3.3.2020]. Available from: https://galvan.cz/galvanickezinkovani/?gclid=EAlalQobChMInILw5uPY6QIVWp3VCh3oxQmvEAAYASAAEgLi8 D BwE

[11] JHA, M.K., KUMAR, V., SINGH, R.J. Review of hydrometallurgical recovery of zinc from industrial wastes. Resources, Conservation and Recycling. [online]. 2001, vol. 33, pp. 1-22. Available from: https://doi.org/10.1016/S0921-3449(00)00095-1.

[12] PUVVADA, G.V.K., MURTH, D.S.R. Selective precious metals leaching from a chalcopyrite concentrate using chloride/hypochlorite media. Hydrometallurgy. [online]. 2000, vol. 58, pp. 185-191. Available from: http://dx.doi.org/10.1016/S0304-386X(00)00083-9.

[13] Liquid waste treatment in galvanizing and zinc electroplating. Industrial wastewater \& air treatment. [online]. Available from: https://condorchem.com/en/blog/treatment-waste-electroplating-industry-zinc-coatings/.

[14] KRIŠTOFOVÁ, D. Recycling of noble metals. Ostrava: VŠB - Technical University of Ostrava, 2001. ISBN 807078-939-5.

[15] BROŽOVÁ, S., DRÁPALA, J., KURSA, M., PUSTĚJOVSKÁ, P., JURSOVÁ, S. Leaching refuse after sphalerite mineral for extraction zinc and cobalt. Metalurgija. 2016, vol. 55, no. 3, pp. 497-499. ISSN 0543-5846. WOS:000372344500054

[16] JACKSON, E. Hydrometallurgical extraction and reclamation. [online]. New York: Ellis Horwood Limited, 1986. Available from: https://doi.org/doi.org/10.1016/0304-386X(87)90057-0. 
[17] HAVLIK, T., ORAC, D., PETRANIKOVA, M., MISKUFOVA, A. Hydrometallurgical treatment of used printed circuit boards after thermal treatment. Waste Manag. [online]. 2011, vol. 31, pp. 1542-1546. Available from: https://doi.org/10.1016/j.wasman.2011.02.012.

[18] GUPTA, C. K. Chemical Metallurgy Principles and Practice., 2003. [online]. Available from: https://doi.org/10.1002/anie.200385071.

[19] AGACAYAK, T., ARAS, A., AYDOGAN, S., ERDEMOGLU, M. Leaching of chlacopyrite concentrate in hydrogen peroxide solution. Physicochemical Problems in Mineral Processing. [online]. 2014, vol. 50, pp. 657-666. Available from: https://doi.org/10.5277/ppmp140219

[20] AHN, J., WU, J., LEE, J. Investigation on chalcopyrite leaching with methanesulfonic acid (MSA) and hydrogen peroxide. Hydrometallurgy. [online]. 2019, vol. 187, pp. 54-62. Available from:

https://doi.org/10.1016/j.hydromet.2019.05.001 